慶應義塾大学学術情報リポジトリ

Keio Associated Repository of Academic resouces

\begin{tabular}{|c|l|}
\hline Title & A Novel Method to Assess Platelet Inhibition by Eptifibatide with Thrombelastograph \\
\hline Sub Title & $\begin{array}{l}\text { トロンボエラストグラフを用いた、糖蛋白IIb/IIIa阻害薬エプティフィバタイドによる血小板機能 } \\
\text { 印制効果の新たな評価法 }\end{array}$ \\
\hline Author & 香取, 信之(Katori, Nobuyuki) \\
\hline Publisher & 慶應医学会 \\
\hline Publication year & 2005 \\
\hline Jtitle & 慶應医学 (Journal of the Keio Medical Society). Vol.82, No.4 (2005. 12),p.15- \\
\hline JaLC DOI & \\
\hline Abstract & \\
\hline Notes & 号外 \\
\hline Genre & Journal Article \\
\hline URL & https://koara.lib.keio.ac.jp/xoonips/modules/xoonips/detail.php?koara_id=AN00069296-2005120 \\
& 2-0015 \\
\hline
\end{tabular}

慶應義塾大学学術情報リポジトリ(KOARA)に掲載されているコンテンッの著作権は、それぞれの著作者、学会または出版社/発行者に帰属し、その権利は著作権法によって 保護されています。引用にあたっては、著作権法を遵守してご利用ください。

The copyrights of content available on the KeiO Associated Repository of Academic resources (KOARA) belong to the respective authors, academic societies, or publishers/issuers, and these rights are protected by the Japanese Copyright Act. When quoting the content, please follow the Japanese copyright act. 


\section{A Novel Method to Assess Platelet Inhibition by Eptifibatide with Thrombelastograph ${ }^{\circledR}$ \\ (トロンボェラストグラフを用いた、粘蛋白 II b/IIIa阻㫪薬エプティフィバタイドによる
血小板機能抑制効果の新たな評価法）}

\section{香 取信之}

\section{内容の要旨}

\section{1. 背然}

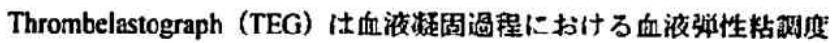
の変化を湖定する楼器であり、TEGのバラメータのーつMaximum

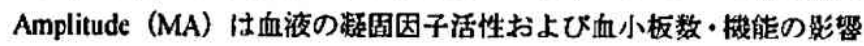

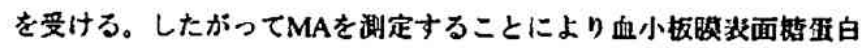
glycoprotein II b/IIIa (GP II b/IIIa) 阻害菓の勃果を検出できると考えら れるが、従来のceliteを用いたTEGでは、GP II b/ll a阻害萝Eptifibatideの

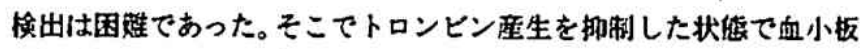
を活性化し、フィフリンとの結合能を剆定なることによって Eptifibatideの血小板族能抑制勃果をより明碇に测定できると仮定し 实路を行った。

2. 材料・方法

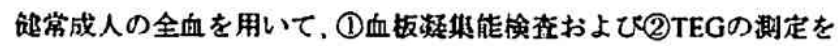
行った。

(1)血小板凝集能榙查 : クエン酸加全血 (Cit恰体)およびヘパリン加 全血 (UH愉体) にEptifibatideを添加し、コントロールとして血小板数 を测定した。またADP添加後の血小板数を測定し、その差から血小板 凝集䒠を咶算した。

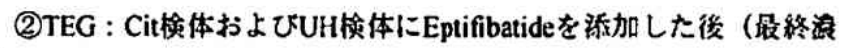

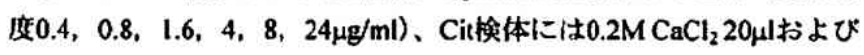
kaolinを（Kaolin TEG）、UH俟体にはbatroxobin-based activator 10ulおよ

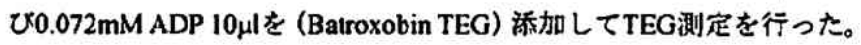

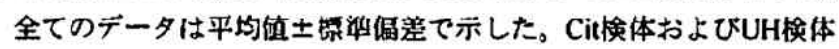
间での血球数の比笠にはpaired t-testを使用した。准集率およびTEG テータはCit検体およびUH娭体間で比胶し、Friedman test、post-hocit Wilcoxon's t-test. Bonferroni被正を探用した $(p<0.01)$ 。

\section{3. 結果}

血小板㠜集能検查では、Eptifibatideの添加によってCit険体、UH検体 ともにコントロールと比较して有意な凝集率の低下を綛めた。Kaolin

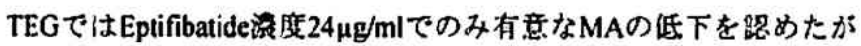
$(56.3 \pm 7.8 \mathrm{~mm}$ vs. $36.9 \pm 7.0 \mathrm{~mm} ; \mathrm{p}<0.01)$ 、Batroxobin TEGでは Eptifibatide㵊度 $0.8 \mu \mathrm{g} / \mathrm{ml}$ 以上で有意なMAの低下を幅めた（44.6士 $7.1 \mathrm{~mm}$ vs. $15.7 \pm 2.3 \mathrm{~mm}: \mathrm{p}<0.01$ )。

4. 結粭

Batroxobin TEGによって、床㵲度であっても検出不可能であった class II GP II b/IIIa阻宫梁Eptifibatideの抗血小板作用を検出すること が可能である。

\section{詥文察查の要旨}

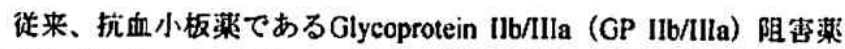
Eptifibatideのin vitroでのモニタリング法としては透過光法による凝

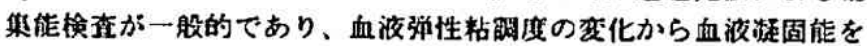
モニターナるThrombelastograph（TEG）を用いて抗血小板作用を挨

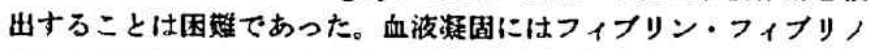
ゲンと血小板のGP IIb/IIIaを介した結合が留要であるが、凝固過程で 産生するトロンビンによって血小板のGP Ilb/IIIaが㨁接话性化される ことがEptifibatideの抗血小板作用のTEGでの検出を困嚾にしてきた と考えた。そこでへハリンによってトロンヒン产生を別制した後に ハトトロキンビンでフィブリンを压生させ、血小板とフィフリンのGP

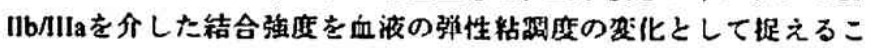
とにより、血小板砯能を検在することが可能であると仮定し研究を 行った。従来のceliteを用いたTEGではEptifibatideの抗血小板作用を 血中港度 $24 \mu \mathrm{g} / \mathrm{ml}$ 以上て検出できたのに対し、ハトロロンヒンを使用 したTEGでは $0.8 \mu \mathrm{g} / \mathrm{ml}$ で検出可佗であった。

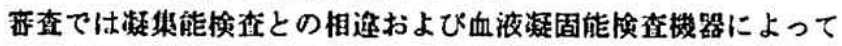

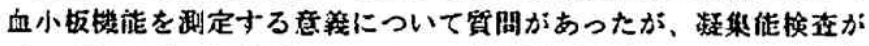
フィフリノダンおよびvon Willebrand因子を介したGP IIb/llaの機㑷 を䀦価するものであるのに対して、今回势案した测定法はGP Ilb/lla を介した血小板とフィフリン網の結合性を測定するため、炡血塊形 成における血小板機能の関与を㤘価可能であると回答された。他の

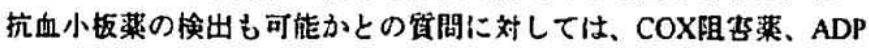
受容体阻客莱なとの娭出さ可能であると回答された。赤血球とフィ

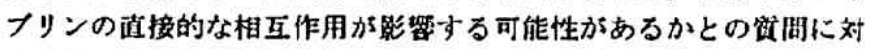
しては、赤血球か受容体を介して㨁接フィフリンと結合ナうことは ないが、血繁成分や血小板数が非常に少ない状点ではその体䅡比が 张性粘明度に影器する可能珄があるため、今後の研究踝避とすると

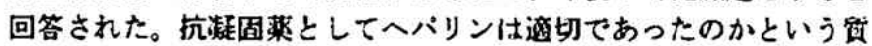
間に対しては、クエン睃ではGP [Jb/lllaの梅造变化をもたら十ため血

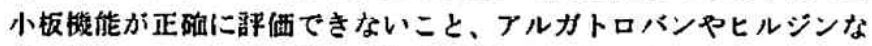
どの抗トロンビン薬であれば使用可能であるが、もっとも讯用性が 高いハハリンを盒択したと回签された。

本研究は今後の臨床忘用について更に娭吋する必装性は残寸もの

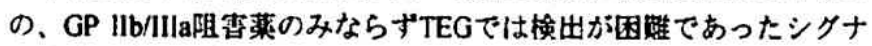

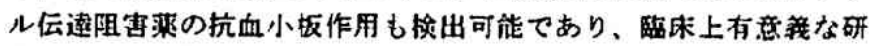
究であると畔価された。

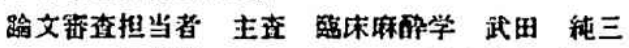

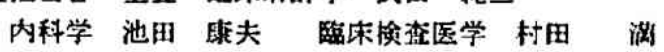
医化学 末讼䧕

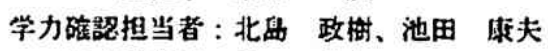

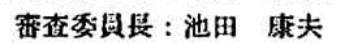

